ISSN 2077-0472

www.mdpi.com/journal/agriculture

Article

\title{
Levels of Sulfur as an Essential Nutrient Element in the Soil-Crop-Food System in Austria
}

\author{
Manfred Sager \\ Competence Centre for Elements, Austrian Agency for Health and Food Safety, Spargelfeldstrasse 191, \\ Vienna A-1220, Austria; E-Mail: manfred.sager@ages.at; Tel.: +43-50555-32801
}

Received: 15 November 2011; in revised form: 27 December 2011 / Accepted: 27 December 2011 /

Published: 12 January 2012

\begin{abstract}
Total sulfur data of various agricultural and food items from the lab of the author, have been compiled to develop an understanding of sulfur levels and ecological cycling in Austria. As sulfur level is not an included factor among the quality criteria of soil and fertilizer composition, the database is rather small. Problems in analytical determinations of total sulfur, in particular digestions, are outlined. As a protein component, sulfur is enriched in matrices of animal origin, in particular in egg white. There is substantial excretion from animals and man via urine. Organic fertilizers (manures, composts) might contribute significantly to the sulfur budget of soils, which is important for organic farming of crops with high sulfur needs. For soils, drainage is a main route of loss of soluble sulfate, thus pot experiments may yield unrealistic sulfur budgets.
\end{abstract}

Keywords: sulfur; food; feed; cereals; manure; fertilizer

\section{Occurrence in Agricultural and Food Items}

For the global continental crust, a mean crust value of $260 \mathrm{mg} / \mathrm{kg}$ sulfur has been generally accepted. Total sulfur in soils at 10 experimental stations in the Czech Republic averaged $221 \mathrm{mg} / \mathrm{kg}$ in 1981 (range 133-334 mg/kg), and slightly decreased to $204 \mathrm{mg} / \mathrm{kg}$ in 2007 (range 105-321 mg/kg), mainly because of lower atmospheric deposition [1].

There is no mean sulfur value for soil in Austria, because sulfur has not been included in the general soil inventory. Only few values about water extractable sulfur exist, which are not representative, and depend on the previous wetting-drying conditions (see Section 6). 
Total sulfur contents is not met among the quality criteria for substances which should improve soil quality and soil nutrient levels, like compost, soil aids, garden moulds and organo-mineral fertilizers, as well as for manures and fermentation residues. Therefore, analysis of total sulfur resp. sulfur fractions is usually not ordered for routine samples, and not much data are available. The data in Table 1 refer to batches occasionally analyzed by the author.

The objective of this study is to compile data of total sulfur contents of samples which have been digested with Mg-nitrate to obtain the total selenium contents; other digests may not be suitable because of sulfur losses in the drying and ashing steps. The manure samples were submitted either by the authorities, or within the frame of projects of the chamber of farmers of the Province of Lower Austria (NÖ Landeslandwirtschaftskammer), to have the levels of nutrients (NPK) and contaminants determined, mainly in 2003 and 2008, and some in between. The urban biowastes were sampled to monitor nutrient contaminants to obtain permission for recycling to agricultural areas. The cereal and food samples have been digested for the analysis of selenium, and have been taken from a project about selenium soil to plant transfer in 1998, as well as from current food monitoring since 2007. At a recent meeting, the author realized that all agriculturalists are focussed on nitrogen and phosphorus cycling, and know almost nothing about sulfur, such as excess, speciation, problems of determination, etc. This essay should encourage decision-makers to take more care about this essential element.

Table 1. Occurrence of sulfur in wastes and coals (in dry mass; number of samples in brackets).

\begin{tabular}{lrrcrc}
\hline \multicolumn{1}{c}{ Sample } & $\mathbf{m g} / \mathbf{k g}$ & Range & $\begin{array}{c}\text { kg for } \\
\mathbf{1 0 0} \mathbf{~ k g ~ P}\end{array}$ & Range & $\begin{array}{c}\text { References } \\
\text { and note }\end{array}$ \\
\hline Mean global continental crust & $\mathbf{2 6 0}$ & - & $\mathbf{2 6}$ & & {$[2]$} \\
Brown coal (75) & $\mathbf{2 1 0 0}$ & $1,300-73,900$ & - & & {$[2]$} \\
Hard coal (26) & $\mathbf{8 2 0 0}$ & $2,700-22,100$ & - & & {$[2]$} \\
Dungs 2003 (18) & $\mathbf{4 7 8 0}$ & $1,480-6,690$ & $\mathbf{2 1 . 8}$ & $15.9-30.8$ & {$[3]$} \\
Manure after biogas production 2003 (26) & $\mathbf{4 6 4 0}$ & $2,800-10,330$ & $\mathbf{3 3 . 6}$ & $17.5-69.4$ & {$[3]$} \\
Manure from Upper Austria 2008 (58) & $\mathbf{2 6 0 0}$ & $1,390-10,960$ & $\mathbf{4 6 . 7}$ & $28.3-365$ & {$[3]$} \\
Urban biowaste 2010, total (44) & $\mathbf{1 9 3 0}$ & $1,200-3,240$ & $\mathbf{7 1 . 5}$ & $39.1-110$ & {$[4]$} \\
Urban biowaste, dry ashed & $\mathbf{7 1 3}$ & $370-1,140$ & $\mathbf{2 5 . 6}$ & $10.8-46.6$ & {$[4]$} \\
Ammonium nitrate lime & $\mathbf{1 1 0}$ & $54-254$ & - & & {$[5,6]$} \\
\hline
\end{tabular}

Sulfur is enriched in the biosphere, which is best demonstrated with coals. They have been formed without human impact. The coal samples [2] were used in thermal power plants in Austria (1986-1987), but of worldwide origin. In coals, the proportion S/P has been estimated from the means. Sulfur concentrations met in manures, dungs and urban biowaste (Table 1) are within the range of coals [2], which means enrichment with respect to mean crust, cereals and green plants. There is obviously less phosphorus in the coals (estimated), which changes the S/P proportion. Results for total sulfur contents of reducing samples may depend on the analytical procedure (see Section 3). In manures and dungs, differences due to the kind of domestic animal, feeding, and region may emerge, but the current database of the author seems to be too small for significant conclusions. 
Outgassing of sulfur compounds during biogas production is an unwanted effect, because they burn to $\mathrm{SO}_{2}$, which corrodes the equipment.

In urban biowaste, which is of partially plant origin, less sulfur and much less phosphorus than in dungs and manures was found, leading to an increase in the S/P proportion.

\section{Sulfur in Feeds and Food}

In the past, many feed and food samples were analyzed for selenium in this lab. Occasionally, the digests were run for sulfur and other elements [7] to detect interelement relationships, which were scarce with sulfur, however. Table 2 contains a compilation thereof. All samples were of Austrian origin, except the rice and possibly some feed components. Because sulfur is primarily a protein component, food of animal origin in general contains more sulfur than food of plant origin. In commercial feeds, higher sulfur levels are met than in cereals. Particularly in mineral feeds and premixes, the sulfur is presumably sulfate as a counter-ion for intentionally added cations.

Table 2. Occurrence of sulfur in green plants, feed and food ( $\mathrm{mg} / \mathrm{kg}$ dry mass) in Austria. The number of samples is given in brackets. Cereals have been investigated at 3 experimental sites in Lower Austria.

\begin{tabular}{lrrr}
\hline \multicolumn{1}{c}{ Sample } & Median, $\mathbf{~ g} / \mathbf{k g}$ & \multicolumn{1}{c}{ Range } & Reference and note \\
\hline Barley grains (30) & $\mathbf{8 2 8}$ & $663-1,020$ & {$[7]$} \\
Winter wheat grains (25) & $\mathbf{8 2 9}$ & $666-1,018$ & {$[7]$} \\
Winter rye grains (20) & $\mathbf{6 9 3}$ & $500-831$ & {$[7]$} \\
Barley straw (30) & $\mathbf{8 7 9}$ & $710-1,186$ & {$[7]$} \\
Winter wheat straw (25) & $\mathbf{8 1 9}$ & $574-996$ & {$[7]$} \\
Winter rye straw (20) & $\mathbf{6 4 1}$ & $365-769$ & {$[7]$} \\
Apple leaves (55) & $\mathbf{1 , 8 6 1}$ & $1,219-2,647$ & {$[3]$} \\
Composite feeds for chicken (35) & $\mathbf{2 , 4 3 0}$ & $1,810-3,700$ & {$[8]$} \\
Supplementary feeds (19) & $\mathbf{5 , 1 5 5}$ & $1,302-7,236$ & {$[3]$} \\
Mineral feeds and premixes (45) & $\mathbf{1 2 , 7 7 9}$ & $5,530-35,574$ & {$[3]$} \\
Egg yolk (42) & $\mathbf{4 , 1 6 7}$ & $2,903-5,316$ & {$[9]$} \\
Egg white (39) & $\mathbf{1 5 , 8 5 8}$ & $11,262-18,426$ & {$[9]$} \\
Bread (17) & $\mathbf{1 , 1 3 1}$ & $520-1,647$ & {$[10]$} \\
Rice, worlwide origin(12) & $\mathbf{9 1 3}$ & $555-997$ & {$[10]$} \\
Chocolate (46) & $\mathbf{7 9 7}$ & $523-1,618$ & {$[11]$} \\
Milk (78) & $\mathbf{2 , 2 9 9}$ & $1,257-2,965$ & {$[3]$} \\
Honey (176) * & $\mathbf{2 1}$ & $6.8-61$ & {$[3]$} \\
dishes with milk/cheese & $\mathbf{2 , 3 1 3}$ & $841-5,249$ & \\
Mainly noodle/rice- dishes & $\mathbf{1 , 0 9 6}$ & $227-4,153$ & {$[12]$} \\
Meat + vegetable dishes & $\mathbf{6 8 1}$ & $385-1,910$ & (data for dishes given \\
Fish dishes & $\mathbf{1 , 5 1 1}$ & $1,481-3,434$ & as fresh weight) \\
Meat dishes & $\mathbf{2 , 4 3 2}$ & $651-3,686$ & \\
Soups & $\mathbf{3 0 9}$ & $129-1,960$ & \\
\hline
\end{tabular}

* estimated value from about equal sample numbers of floral and wood honey; sulfur was partially volatile during digestion. 
In readymade meals for human consumption, sulfur levels are higher in cheese and meat-containing meals. Usually sulfur levels in food are higher than phosphorus [12].

Factor analyses of total concentrations of non-metals in readymade meals showed sulfur in a component opposite to boron, whereas selenium was together with phosphorus and iodine, and silicon was independent from the others. Boron concentrations are usually significantly higher in green plants than in meat, dairy products and cereals, and for sulfur the opposite trend is thus indicated [12].

Contrary to many other trace elements, sulfur intake cannot be increased by changing from white bread to wholemeal bread. When samples of 3 Austrian wheat varieties grown at two different experimental sites were milled on a roller mill, sulfur concentrations found in the brans and the mineral-enriched flour fraction was hardly higher, contrary to most other elements investigated. This is because sulfur is not contained in the mineral cover of the grain, similar to selenium, boron and iodine [13]. Honey is generally low in all trace elements except boron. The samples were digested with nitric acid, and sulfur is partially volatile; the given figures are thus rather an estimation.

\section{Problems in Analytical Sulfur Determinations}

When data from various sources are compared, it should be ascertained that the applied analytical procedures yield compatible results. Standard Reference Materials are dry and of low microbial activity, and thus are not suitable to check the method for reducing wet samples. Therefore, some operationally defined errors have been outlined within this section. Losses of hydrogen sulfide as well as some low-molecular organic compounds during drying, as well as of sulfur dioxide during oxidation processes, may impose severe problems in the analytical method to determine total sulfur. In calcareous matrices, total sulfur analysis is restricted by the limited solubility of gypsum. This can be recognized by using different sample weights. Complexants like EDTA may be useful to dissolve the sample in slightly alkaline solutions.

Mineral fertilizers are usually dissolved in dilute hydrochloric acid, because all their sulfur is assumed to be present as non-volatile sulfate.

From soils, recovery from aqua regia digestion under reflux was about $80 \%$, either from sulfate or methionine (author's experience). Balik et al. [1], however, obtained correct total sulfur in air-dried soils from a nitric-hydrochloric-hydrofluoric acid digest.

For samples of low redox potential, high organic carbon and water content, like manures, drying after addition of a 50\% solution of Mg-nitrate, followed by ashing in the muffle furnace at $560{ }^{\circ} \mathrm{C}$ for 4 hours, was reliable to overcome sample inhomogeneity problems. Oxidizing acids added to the wet sample might be diluted too much to yield effective digestions. Dissolution of the ash in $1+1$ hydrochloric acid in a boiling water bath for half an hour and filtering yields a sample solution suitable for direct determination of selenium and arsenic, as well as of antimony after reduction with $\mathrm{KI} /$ ascorbic acid solution. Selected elements can be determined by ICP-OES, like $\mathrm{Cd}-\mathrm{Cr}-\mathrm{Cu}-\mathrm{Fe}-\mathrm{Mn}-$ $\mathrm{P}-\mathrm{S}-\mathrm{Zn}$, versus calibrants containing equal $\mathrm{Mg}$ matrix amounts. The method was checked by additions of elemental sulfur and methionine. Recovery of sulfur from crystalline sulfides $\left(\mathrm{ZnS}, \mathrm{CuFeS}_{2}, \mathrm{PbS}\right)$, however, is usually better from aqua regia than from Mg-nitrate ashing, because unless crystalline sulfides get completely oxidized, subsequent dissolution of the ash in hydrochloric acid volatilizes the $\mathrm{H}_{2} \mathrm{~S}$. For coals, the Mg-nitrate method yielded correct results (author's experience). 
For the analysis of food, feed and less aqueous organic waste, closed pressure bombs heated by microwaves are suitable, in particular with a solution of K-chlorate in dilute nitric acid. Addition of K-chlorate immediately oxidizes all sulfur and its compounds into non-volatile sulfate. The method was checked by additions of elemental sulfur and methionine. Compared with total contents, dry digestion of urban biowaste samples yielded only 39 (range 16-82\%) of this value, and correlations were poor. Sulfur and many other elements were determined by ICP-OES versus calibrants matched with matrix K-chlorate [14].

Contrary to phosphorus and most metals, the linear range of atomic emission used for the ICP-OES is small, which may lead to underestimations, unless appropriate dilutions are used. The S-180 line is overlapped by a low-sensitive Ca-line, often yielding too high results in real mineral fertilizers; the S-182 line is less sensitive, but more accurate.

\section{Essentiality and Needs of Sulfur}

Sulfur is essentially required to form proteins and coenzymes, its metabolism usually starts with sulfate reduction. Sulfur deficiency results in discoloration and abnormal growth of plant tissues [15]. Sulfur as a protein component is an essential element. In farming, sulfur deficiency symptoms have been well known. S deficiency is more likely to be found on light and shallow soils with low organic matter content, in areas of low atmospheric deposition of $S$, and with excessive winter rainfall [16]. Sulfur deficiency varied between individual years due to the amounts of winter rainfall causing loss of soil sulfate by leaching [17]. Sulfur deficiency may not only lead to decreased yields, but also to poor bread-making quality for wheat [15]. In the UK, oilseed rape, cereals and grasses respond to $\mathrm{S}$ applications of up to 30, 20 and between 20 and $40 \mathrm{~kg} \mathrm{~S} /$ ha, respectively. Also, multicut grass for silage showed to be highly susceptible to S deficiency in the UK and in Ireland [16].

Sulfur is also an essential nutrient for sugarcane crop. Its deficiency has been mostly observed in calcareous and waterlogged soils [18].

\section{Sulfur Input to Soils}

Soil sulfate may originate from atmospheric deposition, fertilizer addition or mineralization of soil organic $\mathrm{S}$, which is the main sulfur fraction.

Currently, main inputs to soils from mineral fertilizers might be via NPK fertilizers, to which sulfate has been added at $2-5 \% \mathrm{~S}$ (e.g., as $\mathrm{K}_{2} \mathrm{SO}_{4}, \mathrm{MgSO}_{4}$, and $\left(\mathrm{NH}_{4}\right)_{2} \mathrm{SO}_{4}$ ). This has to be labeled, and the sulfur contents may frequently exceed the labeled amounts. Within the period 2002-2008, about half of the NPK fertilizers investigated for official state control had these additions in their label, but the usual fertilizer statistics does not discriminate between NPK with and without S, as differences in composition of other elements is negligible [5,6]. For Austria, the annual input of sulfur to arable soils from K-only-fertilizers $\left(\mathrm{K}_{2} \mathrm{SO}_{4}, \mathrm{~K}_{2} \mathrm{SO}_{4} \cdot \mathrm{MgSO}_{4}, \mathrm{KCl} \cdot \mathrm{MgSO}_{4}\right)$ can be assumed at about $0.3 \mathrm{~kg} / \mathrm{ha}$ from the tons and types of K-fertilizer sold, and an arable area of 3.5 million ha [19]. However, use of $\mathrm{K}$-only fertilizers is nonhomogenous over the entire area. Whereas some K-only mineral fertilizers are stoichiometric sulfates, sulfur in ammonium nitrate lime (the most frequently used N-only fertilizer) is low (Table 1). 
Illegal deposition of materials from demolished buildings is a source of gypsum, which is moderately soluble.

The input of sulfur (sulfate) from atmospheric deposition is decreasing, because limits for the emission and cleaning procedures have been established. Total atmospheric S-deposition in the Czech Republic reached top values in 1991 (e.g., Prague region $394 \mathrm{~kg} \mathrm{~S} / \mathrm{ha}$, and North Bohemia $484 \mathrm{~kg}$ S/ha), but desulfurization of thermal power plant emissions decreased the total $\mathrm{S}$ deposition to $10-30 \mathrm{~kg} \mathrm{~S} / \mathrm{ha}$ in 2009 [1]. In the UK, atmospheric deposition ranged from 6-8 kg/ha [20]. At the experimental site, annual inputs from $\mathrm{S}$ from atmospheric deposition measured 1996-1998 were only about 10\% of those recorded during the 1970s in the UK [20]. In Austria, current atmospheric $\mathrm{SO}_{2}$ emissions and the concentrations of dust particles have been monitored by the Federal Environmental Agency [21], but no sulfur deposition data are currently available.

For cereal crops in the UK, optimum $\mathrm{S}$ inputs were between 10 and $20 \mathrm{~kg} / \mathrm{ha}$, given as inorganic sulfate fertilizer in spring just before stem extension. Organic manures may provide these S-quantities also [17] (Section 7).

\section{Sulfur Output from Drainage and Crops}

In arable soils, the main sulfur portion is bound to organic matter [1]. Transfer to crops and washout to the groundwater is governed mainly by formation of soluble sulfate, which is a biologically mediated process. In 1996-1998 in the UK, sulfur leaching losses to the ground water exceeded atmospheric deposition [20].

When NPK fertilizer solution containing sulfate was added on top of repacked chernozem columns in a column experiment in the dark, parts of added sulfur were not retained and moved along the water front like chloride, but dispersion was much lower. This was followed by a constantly low release. After drying, an increased washout of sulfur was noted. Selective leaching of the solid after the experiment showed that there were no shifts in alkali-soluble sulfur in the Gleyic and Haplic chernozem samples during the experiment along the entire profile, but there was significant washout of alkali- soluble sulfur from the top layers from the Calcic chernozem columns [22].

At undisturbed soil monolith lysimeters, having still the natural structure of the soil, $\mathrm{S}$ fertilizers were applied at $50 \mathrm{~kg} / \mathrm{ha}$ in their solid forms at the surface. The lysimeters were covered with grass, and the drainage water was sampled. Soil sulfate was extracted with $0.016 \mathrm{M} \mathrm{KH}_{2} \mathrm{PO}_{4}$ using a soil/solution ratio of 1:5. The release from ammonium sulfate was $72 \%$, from elemental sulfur $26 \%$, and from elemental sulfur sorbed on bentonite only $7 \%$ in the first year. After 3 years, cumulative S-losses were 33, 75 and $96 \%$ of the S applied. The herbage yield increased as late as in the fourth harvest. The slow release of elemental sulfur appears to be suitable as a maintenance fertilizer to grasslands used for hay production or grazing, in particular for temperate regions with a high leaching risk [20].

In spite of high sulfate washout rates, during the decomposition of plant tissues, $\mathrm{Mg}-\mathrm{K}-\mathrm{Ca}$ decrease much more rapidly than N-P-S. After degradation of stinging nettles (Urtica dioica L.), which usually contain much protein and sulfur, and which were grown at sites of high S-emissions, $71-89 \%$ of their total sulfur was lost, and their $\mathrm{C} / \mathrm{S}$ weight ratio increased from 48 to 84 , forming preferably residual $\mathrm{C}-\mathrm{S}$ bound sulfur [23]. Wetland plants can reoxidize sulfide in anaerobic sediments at the surface of their roots to yield sulfate, which may release associate metals to the water column [24]. Thus, 
macrophytes significantly change S-speciation in the pore water profile. Oxygen released from roots of wetland plants into the sediments during the growing season may reoxidize metal sulfides present in the sediment.

Field and pot experiments with cereals done at 3 sites in Lower Austria showed that variations between different years has more influence on the sulfur contents than the soil type or the kind of cereal (wheat-rye-barley). Fertilization was done with an NPK fertilizer 20:8:8, containing 4\% S as soluble sulfate, in fields and pots at the same levels. From the pots (Kick-Brauckmann Type), there was no drainage to the ground water, thus sulfur supply was higher. Whereas the composition of the grain was about constant, excess sulfur was deposited in the straw. The data range of replicates was much closer from the field than from the pot experiments [7] (Table 3). Additionally, the application of phosphorus fertilizers might have increased the mobility of sulfate in the soil [1].

Table 3. Results for the field experiments, means of total sulfur contents in $\mathrm{mg} / \mathrm{kg}$ (from [7]).

\begin{tabular}{|c|c|c|c|c|c|c|c|}
\hline & \multirow{2}{*}{ Crop and year } & \multicolumn{3}{|c|}{ Grains } & \multicolumn{3}{|c|}{ Stalks } \\
\hline & & cambisol & clay soil & chernozem & cambisol & clay soil & Chernozem \\
\hline \multirow[t]{8}{*}{ fields } & maize 98 & 634 & 735 & 732 & & & \\
\hline & maize 99 & 644 & 593 & 452 & 561 & & \\
\hline & $\mathrm{S}$ barley 98 & 871 & 961 & 993 & & & 906 \\
\hline & S barley 99 & 779 & 686 & 716 & 917 & 840 & \\
\hline & W wheat 98 & 913 & 944 & & & 996 & \\
\hline & W wheat 99 & 714 & 763 & 862 & 821 & 730 & 853 \\
\hline & W rye 98 & 764 & 647 & 659 & & 670 & 656 \\
\hline & W rye 99 & 604 & 590 & 753 & 578 & 376 & \\
\hline \multirow[t]{9}{*}{ Pots } & S-barley 1/97 & 1262 & & 740 & 4663 & & 2134 \\
\hline & S-barley 1/98 & 1234 & & 1307 & 2948 & & \\
\hline & S-barley 2/97 & 909 & & 700 & 3061 & & \\
\hline & S-barley 2/98 & 1140 & & 1040 & 259 & & 1995 \\
\hline & D-wheat 1/97 & 1123 & & 543 & 4974 & & 2229 \\
\hline & S-.wheat 1/97 & 1002 & & 835 & 3007 & & 1634 \\
\hline & S- wheat $2 / 97$ & 763 & & 818 & 2324 & & 1858 \\
\hline & W-wheat $1 / 97$ & 1450 & & 888 & 2383 & & 1872 \\
\hline & S-rye 1/97 & 1261 & & 647 & 5760 & & 1938 \\
\hline
\end{tabular}

\section{Recycling of Sulfur}

Usually, fertilization is calculated based on the nitrogen or phosphorus contents of the fertilizer, but in quality control of organic and organo-mineral fertilizers, like manures, dungs, composts, fermentation residues etc. sulfur is not considered (e.g., ÖNORM S 2201 and S 2203). In addition to mineral fertilizers and atmospheric deposition, Withers et al. [17] assumed already in 1997 that manures, urban biowaste and the like might have enough sulfur to provide total sulfur within $10-20 \mathrm{~kg} / \mathrm{ha}$, sufficient for growing cereals. But as their sulfur content is largely unknown, budgets can hardly be made. 
When farmyard manure was supplied at 10 t/ha.year in Bohemia, it contributed $8 \mathrm{~kg} \mathrm{~S} / \mathrm{ha}$, $69 \mathrm{~kg} \mathrm{~N} / \mathrm{ha}, 50 \mathrm{~kg} \mathrm{P} / \mathrm{ha}$ and $50 \mathrm{~kg} \mathrm{~K} / \mathrm{ha}$. Four years application of farmyard manure did not have a significant influence on the proportions of these operationally defined S-fractions in the solid [1]. However, contrary to readily available sulfate from mineral fertilizers, manure and compost additions enrich the soil with slowly available species. Sulfate release from cattle manure in soils follows first order kinetics, and may be quite variable among different soil types, but anyway lower than from compost. With respect to total sulfur present in the original soil, addition of compost and manure changed the release rate in both directions after 10 weeks [25]. Addition of elemental sulfur to cattle manure results in slow formation of sulfate by Thiobacillus thioparus, but the effect is limited to $0.5 \%$ S. Simultaneous lowering of $\mathrm{pH}$ prevents outgassing of ammonia [26].

From the chemical point of view, sulfur and selenium have many similarities. This is not the case in ecological cycling of manures. From factor analysis of total element concentrations found in manures sampled in Upper Austria 2008, the first factor contained the essential elements added to commercial feeds ( $\mathrm{Se}-\mathrm{Cu}-\mathrm{Zn}-\mathrm{P})$, the second contained $\mathrm{S}$ together with $\mathrm{K}-\mathrm{Na}$, and the third the rest (Fe-Cd). In 58 samples, a median of $2600 \mathrm{mg} / \mathrm{kg}$ total sulfur was found (in about Gaussian frequency distribution), which is 10-times the mean crust value. The frequency distribution of the proportion sulfur/phosphorus, however, was rather logarithmic, the median of $\mathrm{mg} / \mathrm{kg}$ sulfur over $\mathrm{mg} / \mathrm{kg}$ phosphorus was 0.467 [3].

Contrary to green plants in the temperate climate zone, concentrations met in urban biowaste did not show annual cycling. Conventional dry ashing yielded $39 \pm 16 \%$ of the total sulfur obtained from the digestion in closed vessels with K-chlorate/nitric acid. One outlier was noticed in December, which was presumably sulfate [4].

Apart from exact separation techniques, the distribution of sulfur contents between solid and liquid fractions might be estimated from the excretion metabolism of the animal or man. Until now, no urine samples from domestic animals were available. But fortunately, human urine was sampled from pregnant women in a hospital, to investigate their iodine status. From the digests obtained, some other elements could be determined by ICP-OES, like sulfur (Table 4). Usually, concentrations in manure are given in $\mathrm{mg} / \mathrm{kg}$ dry mass, and in urine samples in $\mathrm{mg} / \mathrm{L}$. If excretion of 1 liter per day containing 50-72 $\mathrm{g}$ dry substance is assumed, this results in a factor of 14-20 between the figures for manures and urine. The data are presented to demonstrate that the proportion of sulfur excreted in liquid form is almost as large as for sodium (Table 4). High $\mathrm{Na}$ levels are typical for human urine samples. 
Table 4. Concentrations found in manures of domestic animals versus human urine.

\begin{tabular}{crrrrr}
\hline & Manures in dry matter $(\mathbf{m g} / \mathbf{k g})$ & \multicolumn{1}{c}{ Human } & urine & $\mathbf{N}=\mathbf{7 8})(\mathbf{m g} / \mathbf{L})$ & Manure/urine \\
\hline $\mathrm{Na}$ & $\mathbf{9 , 4 1 0}$ & $620-68,500$ & $\mathbf{2 , 6 5 0}$ & $606-5,632$ & 3.55 \\
$\mathrm{Mg}$ & $\mathbf{7 , 3 2 0}$ & $1,630-21,900$ & $\mathbf{5 2 . 0}$ & $14.9-175$ & 141 \\
$\mathrm{Ca}$ & $\mathbf{2 8 , 8 0 0}$ & $7,370-57,200$ & $\mathbf{1 1 3}$ & $20-374$ & 255 \\
$\mathrm{Sr}$ & $\mathbf{5 3 . 4}$ & $13.1-119$ & $\mathbf{0 . 1 3 3}$ & $0.043-0.388$ & 402 \\
$\mathrm{Ba}$ & $\mathbf{3 7 . 4}$ & $10.0-114$ & $\mathbf{0 . 0 0 5}$ & $<0.004-0.064$ & 7,480 \\
$\mathrm{Fe}$ & $\mathbf{2 , 8 1 0}$ & $480-10,260$ & $<\mathbf{0 . 1}$ & $<0.1-0.28$ & $<28,000$ \\
$\mathrm{Cu}$ & $\mathbf{6 4 . 7}$ & $8.5-568$ & $\mathbf{0 . 0 4}$ & $<0.01-0.13$ & 1,618 \\
$\mathrm{Zn}$ & $\mathbf{3 1 6}$ & $37.1-2,327$ & - & - & - \\
$\mathrm{P}$ & $\mathbf{1 4 , 0 0 0}$ & $3,900-35,100$ & $\mathbf{3 1 9}$ & $47-799$ & 43.9 \\
$\mathrm{~S}$ & $\mathbf{3 , 6 9 0}$ & $188-8,760$ & $\mathbf{3 6 3}$ & $127-932$ & 10.2 \\
$\mathrm{~J}$ & & & $\mathbf{0 . 0 8 0}$ & $0.012-0.201$ & \\
\hline
\end{tabular}

\section{Conclusions}

Sulfur contents of agricultural and urban organic wastes are not negligible. There are needs to recycle theses wastes as fertilizers to arable soils in order to maintain sufficient organic carbon levels, provided contaminant levels are low. Some mineral fertilizers may contain more sulfur than the organics, particularly if $2-5 \%$ sulfate has been added, or in case of some K-only fertilizers. On the other hand, sulfur addition from organics is more sustainable because of rapid washout of sulfate.

If mineral fertilizers are substituted by organics, like manures, dungs, composts, and urban biowaste, beneath the main nutrients NPK and the so-called heavy metals, there is a need to know the total sulfur contents as well, and to get an idea about its release rate, in order to satisfy crop needs. Sulfur contents of organic fertilizers should be considered among the parameters assessed to characterize their quality and sustainability, with respect to sulfur needs of special crops, in particular in case of organic farming practices.

These data show that total sulfur contents in food, feeds and organic fertilizers may be highly variable, and the data depend on the analytical method used. Because atmospheric sulfur deposition is fortunately declining, sulfur as an essential element should be also considered in nutrient budgeting.

\section{References and Notes}

1. Balik, J.; Kulhanek, M.; Černy, J.; Szakova, J.; Pavlikova, D.; Čermak, P. Differences in soil sulfur fractions due to limitation of atmospheric deposition. Plant Soil Environ. 2009, 55, 344-352.

2. Sager, M. Environmental aspects of trace elements in coal combustion. Tox. Environ. Chem. 1999, 71, 159-183.

3. Sager, M. Austrian Agency for Health and Food Safety: Vienna, Austria. Unpublished work, 2012.

4. Sager, M. In Element Composition from Urban Bio-Waste Compared with Organic Fertilizers of Agricultural Origin; Nriagu, J., Ed.; Progress in Environmental Science, Technology and Management; Progress on Heavy Metals in the Environment; Maralte: Leiden, the Netherlands, 2011. 
5. Sager, M. Fertilization Loads of Less Common Elements to Arable Soils in Austria-Chapter 7. In Organic Farming: Methods, Economics and Structure; Nelson, M., Artamova, I., Eds.; Nova Science Publishers: New York, NY, USA, 2009.

6. Sager, M. Trace element enrichment in austrian soils from fertilization, and regional effects. Dyn. Soil Dyn. Plant 2009, 3, 115-131.

7. Sager, M.; Hoesch, J. Macro- and microelement levels in cereals grown in lower Austria. J. Central Eur. Agric. 2005, 6, 461-472.

8. Sager, M. Relations between the elemental composition of hens' eggs and feeds. Die Bodenkultur, submitted for publication, 2012.

9. Sager, M. Mengen- und Spurenelemente in österreichischen Hühnereiern. Ernährung Nutr. 2011, $35,53-58$.

10. Sager, M. Druckaufschluss mit salpetersaurer Kaliumchloratlösung für die Spurenanalyse in pflanzlichem Material. In Proceedings of the ALVA Jahrestagung, Stadtschlaining, Austria, 21-22 May 2007.

11. Sager, M. Chocolate and cocoa products as a source of essential elements in nutrition. J. Nutr. Food Sci., submitted for publication, 2012.

12. Sager, M. Über die Elementzusammensetzung von in Österreich erhältlichen Fertiggerichten und Wurstwaren. Ernährung Nutr. 2010, 34, 57-64.

13. Sager, M.; Werteker, M. Zur Elementverteilung in Mahlfraktionen von Weizen an zwei niederösterreichischen Standorten. Ernährung Nutr. 2010, 34, 357-367.

14. Sager, M. Microwave-assisted digestion of organic materials with $\mathrm{KClO}_{3} / \mathrm{HNO}_{3}$ for the analysis of trace metals and non-metals. Anal. Chem. Indian J. 2011, in press.

15. Schiff, J.A. Reduction and other metabolic reactions of sulfate. In Inorganic Plant Nutrition; Läuchli, A., Bieleski, R.L., Eds.; Springer Verlag: Berlin, Germany, 1983.

16. Zhao, F.J.; McGrath, S.P.; Blake-Kalff, M.M.; Link, A.; Tucker, M. Crop responses to sulphur fertilisation in Europe. In Proceedings of the Conference of the International Fertiliser Society, Cambridge, UK, 16-17 December 2002.

17. Withers, P.J.A.; Zhao, F.J.; McGrath, S.P.; Evans, E.J.; Sinclair, A.H. Sulphur inputs for optimum yields of cereals. Aspects Appl. Biol. 1997, 50, 191-198.

18. Yadav, R.L.; Yadav, D.V.; Shukla, S.K. Improving yield and quality of sugarcane through secondary and micronutrients. Indian J. Fertil. 2009, 5, 99-105.

19. Dachler, M.; Kernmayer, I. Düngemittelaufwand in Österreich. In Bodenschutz in Österreich; Bundesministerium für Land- und Forstwirtschaft: Wien, Austria, 1997.

20. Riley, N.G.; Zhao, F.J.; McGrath, S.P. Leaching losses of sulphur from different forms of sulphur fertilizers: A field lysimeter study. Soil Use Manag. 2002, 18, 120-126.

21. Federal Environmental Agency Home Page. Available online: www.umweltbundesamt.at (accessed on 28 December 2011).

22. Sager, M. Vertical mobility of selenium, arsenic and sulfur in model soil columns. Die Bodenkult. 2002, 53, 83-103.

23. Zucker, A. Dynamik verschiedener schwefelfraktionen bei abbauversuchen mit brennesselblättern (urtica dioica L.). Z. Pflanzenern. Bdk 1987, 150, 168-173. 
24. Choi, J.H.; Park, S.S.; Jaffé, P.R. The effect of emergent macrophytes on the dynamics of sulfur species and trace metals in wetland systems. Environ. Poll. 2006, 140, 286-293.

25. Saviozzi, A.; Cardelli, R.; Cipolli, S.; Levi-Minzi, R.; Piffaldi, R. Sulphur mineralization kinetics of cattle manure and green waste composts in soils. Waste Manag. Res. 2006, 24, 545-551.

26. Gu, W.J.; Zhang, F.B.; Xu, P.Z.; Tang, S.H.; Xie, K.Z.; Huang, X.; Huang, Q.Y. Effects of sulphur and thiobacillus thioparus on cow manure aerobic composting. Bioresour. Technol. 2011, 102, 6529-6535.

(C) 2012 by the authors; licensee MDPI, Basel, Switzerland. This article is an open access article distributed under the terms and conditions of the Creative Commons Attribution license (http://creativecommons.org/licenses/by/3.0/). 